\title{
Influence Factors of Adoption E-commerce in Iraqi SMEs
}

\author{
Ahmed Luay Ahmed \\ Supervision and Scientific Education Apparatus, \\ International Accreditation Department, Ministry of Higher Education, \\ Iraq \\ ahmed.qacc@gmail.com
}

Recived : $11 \backslash 12 \backslash 2017$

Revised : $14 \backslash 1 \backslash 2018$

Accepted : 17\112018

Available online : $\quad 20 / 2 / 2018$

DOI: 10.29304/jqcm.2018.10.2.370

\begin{abstract}
Today the most significant technologies that change the business environment is the Internet that has a great effect on the future of electronic commerce (e-commerce). Currently e-commerce plays a vital role in the development of small and medium enterprises (SME). Therefore, Iraq must involve its SME in this field in order to no longer be separated from the business world and the new economy. The objective of this paper is to identify the factors that prevent the adoption e-commerce by SME. The researcher prefers to use qualitative and quantitative approach due to identify these factors. The results showed the most important factors that affect directly and must be considered in order to adoption of e-commerce in SME. Adoption these factors will help Iraqi SME's to gain long term success in the global market.
\end{abstract}

Keyword: e-commerce, SME, success factors adoption 


\section{Introduction}

The advent of the Internet has generated a plethora of opportunities for businesses to communicate, collaborate, and distribute information, which will lead to fundamental changes in the way companies compete with one another and provide services to their customers [1].

Contrary to the traditional means of conducting the transactional commerce which is dependent on buying and selling goods and services face-to-face, and require physical environment, the Internet can bring down physical barriers to commerce and offers access to the virtual market which could reach millions of customers on the Internet [2].

Furthermore, companies are taking advantage of Internet technologies to include more than just buying and selling online and conduct other commercial activities ranging from simple advertising to comprehensive virtual brochures. The conception of buying and selling of goods and services and transfer of funds through digital communications is termed as "electronic commerce" or simply "e-commerce". E-commerce offers privileges and new means of doing business that no company can afford to ignore.

With the increased unemployment rates and major companies downsizing, the small- medium size enterprise (SME) is encouraged as one major solution to the new economies issues, due to its ability to create jobs, address poverty and improve productivity. As such, SMEs represent the backbone of the national economy in most countries all over the world. It is essential for an SME to grow in order to remain competitive in the current and future markets. The SMEs through the use of the Internet and e-commerce will be able to enhance internal and external communication, shorten the development cycle of new products, access new geographical markets domestically and internationally, reduce the export costs, and provide support to customers. Furthermore, ecommerces will contribute to make SME to overcome the disadvantage of being small in size to reach customers especially in international markets and establishing new distribution channels. Ecommerce is no longer an alternative; it is an imperative for SME to survive. However, many firms still struggle on which would be the best model to adopt e-commerce and which strategy should be followed? The answer is not simple, every firm has its special circumstances and resources and there is no e-commerce model that fits all the companies in spite of being in the same culture or the same size. Therefore, every company must be required to review e-commerce models before deciding which strategy or model is suitable to be adopted?

\section{A. Small and Medium Enterprise (SME)}

There are many varying definitions for SME. According to some research, small and mediumsized enterprises (SMEs) can be described as an aggregate group of businesses operating in many sectors such as services, trade, agri-business, and manufacturing. They include a wide diversity of firms such as village handicraft makers, small machine shops, and computer software firms that have a wide range of sophistication and skills. Some are dynamic, innovative, growth-oriented and fast-growing firms while others are satisfied to remain small and perhaps family owned with no change for decades. Size-wise, SME may range from part-time business with one employee to a business employing hundreds of people. 
Ahmed .L

They range from SME which are inextricably part of an international subcontracting network, or to those with technology and investment partners based aboard, or to those which are part of a family-based society or cluster[3],[4].

The official definition of SME in Iraq by the Central Organization for Statistic and Information Technology (COSIT), an Iraqi Government Body is small business that has the number of employees less than 10, and medium business which has less than 30 employees (See the table 1). Due to this definition used by Iraqi Government and most of the NGOs in Iraq, this definition will be admitted for the purposes of this research.

Table 1: Definition of Small and Medium Enterprises in Iraq.

\begin{tabular}{|c|c|}
\hline Small enterprise & Employee 1-9 people \\
\hline Medium & Employee 10-29 people \\
\hline
\end{tabular}

\section{B. E-Commerce}

Electronic commerce or e-commerce refers to the process of selling and buying through the Internet, or conducting any transaction including the transfer of ownership or rights to use services or goods via a computer-mediated network. Execute these transactions electronically will provide wide competitive advantages by finding new customers, markets, and suppliers. Additionally, e-commerce is often faster where it overcomes the geographical boundaries; e-commerce is also cost-effective, where the advertising and marketing is at a lower cost compared with traditional methods. In addition e-commerce does not need a prominent physical location [5].

\section{Benefits Derived from Adopting E-Commerce within SMEs.}

E-commerce brings numerous benefits to those SMEs that adopt e-commerce[6],[1]. According to Payne (2005)[7], the e-commerce will not benefit all the economic sectors in the same way, he suggests that the sectors that have informationintensive activities and product or services that can be used or delivered by electronic means the most likely to benefit from e-commerce. In this section, the researcher will explore some of the plausible benefits reported in literature studies.

The researcher summarizes the benefits from ecommerce to SMEs as follows:

1- Cost saving: e-commerce works on reducing transactional and communicative cost, inexpensive advertisement, provide cost effective ways to marketing[8],[9],[10].

2- Time-saving: shortening the development cycle of new products, reducing the search information time; in addition reducing stock lead times [2],[11],[6].

3- Enhancing ability for competition it enables SME to overcome limitation and to maximize using information and network technology hence it provides the efficiency for SME to compete with large companies as well as the another SMEs[12],[13],[14].

4- Reaching new local and global markets that means new supplier and customers and enhance the profitability[12],[13], [15].

5- Improving communication to use internet by SMEs will enhance internal and external communication, and achieve two-ways of communication, provide support to customer's services [2],[13]. 


\section{Development of the Research Tool (Data Collection)}

As there is lacking of research done in developing countries regarding the adoption of e-commerce in SMEs especially in a country like Iraq, a survey tool was developed for collecting data necessary in this study. This approach has been considered being the most suitable due to the lack of empirical research in Iraqi environment [4]. Furthermore, the researcher prefers to use qualitative approach (survey) due to the current study's main intention that is the identification of the significant factors that influence the e-commerce adoption and implementation in SMEs. This was done by conducting a thorough literature review of studies investigating such factors and by conducting interviews with academic and business experts who have sufficient knowledge to deal with e-commerce adoption. The researcher later used these study results to conduct a comprehensive survey in the area of Baghdad to further test these qualitative results. This research design has been successfully employed in similar studies[16].

Although the survey method has its own advantages and limitations, the survey approach appeared as more popular among researchers and enabled generalization of the finding. For this reason, two tools were adopted in this research: the interview and questionnaire.
After collecting the data from the interview and the subsequent questionnaire, data analysis session took place. Here in, Statistical Package for the Social Science (SPSS) which is a statistical tool was used for analyzing the data by using descriptive statistics to illustrate the demographic information. Each time the collected data was inserted, data analysis was performed. To ensure useful findings which reflect the prospective of the respondents, the researcher paid much attention for analyzing the results which was considered as one of the most significant step during the data analysis phase.

\subsection{Interview}

Knowledge that can be extracted from human is called the knowledge elicitation. Eliciting knowledge requires many sessions. These sessions may be interactive discussions that involve an exchange of ideas about the problem. This style of acquiring knowledge is known as interview method. First of all, the main objective of the interview should be highlighted and obvious to ensure the success of the interview. Based on that, the objective of the interview was to investigate what are the most important factors which may drivelinhibit e-commerce in Iraqi environment. The researcher had two candidates for the purpose of the interview. Table 2 illustrates the people who were interviewed and consulted. 
Ahmed .L

Table 2: List of people Interviewed and Consulted

\begin{tabular}{|c|c|c|}
\hline No. of Experts & Expert 1 & Expert2 \\
\hline Name & Dr. Saif Alsewaidi & $\begin{array}{l}\text { Assitant prof . Dr. Firas Abdul- } \\
\text { hamed }\end{array}$ \\
\hline Organization & Fnjancom company, Iraq & Baghdad University, Iraq \\
\hline Years of experience & 5 & 15 \\
\hline Remarks & $\begin{array}{l}\text { - He works for more than five years in the field of e- } \\
\text { commerce in Iraq } \\
\text { - The Fnjancom Company is a pioneer in adopting e- } \\
\text { commerce in Iraq and it's the official sponsor for } \\
\text { the first conference conducting in Iraq about e- } \\
\text { commerce in } 2010 \text {. } \\
\text { - Fnjancom company provides service of "gate } \\
\text { online shopping" through the "Filspay" credit card } \\
\text { which is a mean to pay online instead of use cridet } \\
\text { cards such as Visa or Master card (for security } \\
\text { issues), and consider it as a solution for people who } \\
\text { do not have credit card. }\end{array}$ & $\begin{array}{l}\text { - Head of computer science } \\
\text { department. } \\
\text { - Teaching the principals of the e- } \\
\text { commerce for 5years. } \\
\text { Work as web-designer for } \\
\text { commercial purposes for more than } \\
4 \text { years. }\end{array}$ \\
\hline
\end{tabular}

As portrayed in Table 2, Mr. Saif represented the practical and business experience while Dr. Firas represented the academic and IT experience.

The researcher took into consideration the importance of preparing a list of materials that was to be discussed during the interview in order to focus on the target of this interview and time factor. The interview's agenda detailed on how to achieve the objective and contained a list of the major items that was to be discussed during the interview.

The success of any interview session will first rest with the background formed by its preparation. The preparation addressed the subjects to be covered, scheduling, materials and methods for recording the session. For the purpose of this research, the researcher prepared the material to be discussed with the interviewees based on a thorough review of literature and consultation. The first interview was essential since it had a major impact on enhancing or reducing further interview sessions.
In the second session of the interview, the important factors that influence adopting ecommerce in developing countries were demonstrated and discussed.

The type of interview used in this research was a structured interview because it was easier to prepare and manage than an unstructured interview. The information collected was also easier to be analyzed since most of the information collected was related. Finally, this approach provided more detailed information on the problem.

From the results collected from the interviewe, the questionnaire was designed. Apart from this, there were some questions in the questionnaire that were adopted from previous questionnaires [17],[4],especially questions that had already been validated. The researcher then showed the questionnaire in both English and Arabic versions to the interviewees and asked them for their assessment regarding the questionnaire in general. 
Finally, the researcher revised the questionnaire based on the suggestions given so as to be more understandable for the respondents.

\subsection{Questionnaire}

The second method for collecting information was by conducting the questionnaire. The questionnaire is a way commonly used to collect large number of data in a short time. Iraq has suffered from heavy lack of power supply; in addition, there is no legislation from the government to protect the local product, thus these reasons led to the closedown of most SMEs from the manufacturing nature in Iraq. The researcher distributed the questionnaire to 30 SMEs chosen randomly in Baghdad. The feedback was obtained from 23 responding SMEs. The respondents were owners, managers of the computer stores in Iraq who were considered as qualified to speak about recent technology development due to their exposure to technology.

The questionnaire was divided into 4 sections and included 27 questions. The first section consisted of 8 questions about the profile of the firmlcompany and some managerlowner's characteristics were included. While the other three sections (2, 3 and 4) used Likert scale to show the level of respondent's agreement about the question "why your firmlcompany is not using e-commerce?", where the respondent were asked to rank their answers based on 5 levels; from level 1 as strongly disagree to level 5 as strongly agree. The second section included 7 questions focused on technological factors that have influenced the e-commerce adoption in Iraq. The third section included 6 questions emphasizing on the macro and micro environmental factors and lastly the forth section included 6 questions about organizational factors. Due to commercial confidentiality, the names of the respondents were kept undisclosed.

\section{Data Collection and Analysis}

The following sections provide a detailed description for the results of data collection and analyses:

\subsection{Reliability}

Mitchell (1996)[18] indicated that the reliability of the questionnaire is concerned with the consistency of the response to the questions. Reliability can be defined as the accuracy or precision of measuring instrument. The reliability analysis has been applied to verify the collected data allows the researcher to study the properties of measurement scales and items that make them up. For the purpose of the reliability analysis, the Cronbach's Alpha has been estimated. Alpha Cronbach can be defined as a model of internal consistency based on the average inter-item correlation. In this research, the Alpha value for the variables which indicate the reliability of construct is as follows:

Table 3: Reliability of the Questionnaire

\begin{tabular}{|c|c|c|}
\hline $\begin{array}{c}\text { No. of } \\
\text { items }\end{array}$ & $\begin{array}{c}\text { Cronbach's Alpha } \\
\text { Based on } \\
\text { standardized items }\end{array}$ & $\begin{array}{c}\text { Cronbach's } \\
\text { Alpha }\end{array}$ \\
\hline 19 & 0.920 & 0.918 \\
\hline
\end{tabular}

By analyzing the questionnaire data using SPSS, the researcher found Cronbach's Alpha equal to 0.918 , thus, the reliability of the data is acceptable since the percentage of Cronbach's Alpha can be considered acceptable if it not less than 0.7[19]. 
Ahmed .L

\subsection{Descriptive Analysis for}

\section{Demographic Questions}

As presented in Table 4, results from the questionnaire showed that 23 owners/managers of the SMEs responded to the questionnaire where 74 $\%$ of them are Small Enterprises and $26 \%$ are Medium Enterprises according to the official Iraqi definition for SME. 57\% from the enterprise respondents are under 5 employees. Besides that, the results of the questionnaire indicated that $39 \%$ of the surveyed companies have experience of 4-6 years, while those who have experience with ten years and more were 35\%. Among those who responded, $52 \%$ were within the age group of 30 39 years old, while the percentage of people who were within the age group of 20-29 years old was $9 \%$. The questionnaire results also showed that the majority of respondents hold a degree (Bachelor) where the proportion of $65 \%$ of the total respondents. The results of the questionnaire indicated that $95 \%$ of respondents have at least one computer and Internet service, used email and mobile to conduct business transactions. This is an indication of the large penetration of computers and the Internet through Iraqi business community. Finally the percentage of the enterprises that have their own website formed $26 \%$ from the respondents.
Table 4: Descriptive Analysis of the Respondents

\begin{tabular}{|c|c|c|c|}
\hline Variable & Classification & Freq. & Perce. \\
\hline \multirow{4}{*}{$\begin{array}{l}\text { Size of company } \\
\text { (number of } \\
\text { employees) }\end{array}$} & Below 5 & 13 & $57 \%$ \\
\hline & 5- 9 & 4 & $17 \%$ \\
\hline & $10-20$ & 5 & $22 \%$ \\
\hline & $21-29$ & 1 & $4 \%$ \\
\hline \multirow{4}{*}{$\begin{array}{l}\text { Number of years } \\
\text { firm in business }\end{array}$} & $0-3$ & 1 & $4 \%$ \\
\hline & $4-6$ & 9 & $39 \%$ \\
\hline & $7-9$ & 5 & $22 \%$ \\
\hline & 10 and above & 8 & $35 \%$ \\
\hline \multirow{4}{*}{$\begin{array}{l}\text { Age of ownerl } \\
\text { Manager }\end{array}$} & 20-29 years & 2 & $9 \%$ \\
\hline & $30-39$ years & 12 & $52 \%$ \\
\hline & $40-49$ years & 7 & $30 \%$ \\
\hline & $50-59$ years & 2 & $9 \%$ \\
\hline \multirow{5}{*}{$\begin{array}{l}\text { Education } \\
\text { Level }\end{array}$} & $\begin{array}{c}\text { secondary } \\
\text { school }\end{array}$ & 2 & $9 \%$ \\
\hline & Diploma & 2 & $9 \%$ \\
\hline & Bachelor & 15 & $65 \%$ \\
\hline & Master & 2 & $9 \%$ \\
\hline & $\mathrm{PhD}$ & 2 & $11 \%$ \\
\hline \multirow{2}{*}{$\begin{array}{l}\text { The enterprise has } \\
\text { internet provider }\end{array}$} & Yes & 22 & $96 \%$ \\
\hline & No & 1 & $4 \%$ \\
\hline \multirow{2}{*}{$\begin{array}{l}\text { The enterprise has } \\
\text { website }\end{array}$} & Yes & 6 & $26 \%$ \\
\hline & No & 17 & $74 \%$ \\
\hline \multirow{2}{*}{$\begin{array}{l}\text { The enterprise uses } \\
\text { email and mobile to } \\
\text { conduct businesses }\end{array}$} & Yes & 22 & $96 \%$ \\
\hline & No & 1 & $4 \%$ \\
\hline
\end{tabular}

\subsection{Analysis Questions for}

\section{Technological Factors}

This section shows the most significant factors that affect adopting e-commerce from technological contexts.

Table 5: Response to the Technological Factors

\begin{tabular}{|l|c|}
\hline Technological factor & Mean \\
\hline IT infrastructure- e payment system & 3.95 \\
\hline IT infrastructure-power supply & 3.65 \\
\hline Security & 3.52 \\
\hline Perceived ease of use & 2.56 \\
\hline Perceived usefulness & 2.26 \\
\hline Compatibility & 2.13 \\
\hline Time & 1.95 \\
\hline
\end{tabular}


Ahmed .L

As the researcher found in Table 5, majority respondents believe that the lack of IT infrastructure (regarding both e-payment system and power supply) and security concern in payment over the Internet constitute the most important technological factors that inhibit adopting of ecommerce in Iraq.

\subsection{Analysis Questions for}

\section{Environmental Factors}

Following table illustrates the factors that affect adopting e-commerce from environmental contexts

Table 6: Response to the Environmental factors

\begin{tabular}{|l|c|}
\hline \multicolumn{1}{|c|}{ Environmental factor } & Mean \\
\hline Government support & 4.39 \\
\hline Political pressure & 4.2 \\
\hline Market Orientation & 3.7 \\
\hline Customer demand & 3.5 \\
\hline Absence of examples & 3.2 \\
\hline Competitors & 2.3 \\
\hline
\end{tabular}

Table 6 shows that majority respondents believe the external pressure from lack of government support and unstable security represent the most important factors that hinder the adopting of ecommerce.

\subsection{Analysis Questions for}

\section{Organizational Factors}

This section shows the most important factors that affect adopting e-commerce from organizational contexts.

Table 7: Response to the Organizational Factors

\begin{tabular}{|l|c|}
\hline Organizational factor & Mean \\
\hline IT skills & 3 \\
\hline Organization resistance & 2.82 \\
\hline e-commerce awareness & 2.8 \\
\hline Organization financial readiness & 2.7 \\
\hline Organization technology readiness & 2.6 \\
\hline Top management & 2.1 \\
\hline
\end{tabular}

The researcher observed in Table 7 that the respondents believe that the lack of IT skills or ecommerce skills represent the most important factor from the organizational factors that need to be dealt with before embracing e-commerce businesses in Iraq.

\section{Finding Discussion}

In this study the results of the questionnaire to 23 Iraqi SMEs in services sector have been presented and analyzed by using SPSS, the purpose of the questionnaire was intended to find out some of Iraqi SMEs potentials, owners/managers characteristics and SMEs willingness to adopt ecommerce, and the most important factors that impede the adoption of electronic commerce in Iraq from the technological, environmental, and organizational aspects. The results obtained from the analysis of questionnaire are following:

- Results showed that the percentages of small companies which have workers fewer than 5 persons are $57 \%$. The highest percentage of those respondents was managers/owners of SMEs who are between 30-39 years and most of them are bachelor degree holders.

- Majority of the SMEs respondents use the internet and email to conduct business operations, while the respondents from companies that have their own websites are $26 \%$.

- IT infrastructure and security concern is the most important technological factors that inhibit adopting of e-commerce in Iraq.

- The government support being the most important Environmental factors which inhibit adopting e-commerce.

- The results revealed that the IT skills are the most important factors that affect the adoption from organizational perspective. 


\section{Conclusion}

E-commerce plays an increasingly important role in the development of Iraqi SMEs. Mixed approaches which are questionnaires and interview have been used in this study to identify the factors that effect upon the adoption of e-commerce in SME. The finding from this study illustrated that there are many important factors that help to adopt ecommerce in small and medium enterprises, which have a positive role in the development of ecommerce in Iraqi local and global market.

\section{References}

[1] Thomas, B. and Simmons, G. "E-Commerce. "Adoption and Small Business in the Global Marketplace: Tools for Optimization." IGI Global, 2010. 1-399. Web. 1 Jun. 2012. doi:10.4018/978-1-60566-998-4

[2]Iqbal, Z.(2007). "Role of the Internet in SME Growth Strategies."Master Thesis, Lulea University of Technology

[3]Harvie, C. and B. C. Lee. (2002). "The Role of SMEs in National Economies in East Asia."Edward Elgar Publishing.

[4]Kapurubandara, M. and R. Lawson. (2006). "Barriers to Adopting ICT and E-commerce with SMEs in Developing Countries: an Exploratory Study in Sri Lanka." CollECTeR (Collaborative Electronic Commerce Technology and Research).

[5]Kapurubandara, M., S. Arunatileka, et al. (2004). "Application of E-Business Strategies for SMEs in Developing Countries. "ETechnology, E-Commerce and E-Service, 2004. EEE 04. 2004 IEEE International Conference on.
[6]MacGregor, R. and L. Vrazalic. (2004). "Electronic Commerce Adoption in Small to Medium Enterprises (SMEs)." A Comparative Study of SMEs in Wollongong (Australia) and Karlstad (Sweden), University of Wollongong.

[7]Payne, J.E. 2005. "E-commerce Readiness for SMEs in Developing Countries. " A Guide for Professionals. PP2.

[8]Cloete, E., S. Courtney, et al. (2002). "Small Businesses: Acceptance and Adoption of ECommerce in the Western Cape Province of South Africa." The Electronic Journal of Information Systems in Developing Countries10(0).

[9]Bolongkikit, J., Obit, J.H., Asing, J.G. and Tanakinjal, G.H. (2006). "An Exploratory Research of the Usage Level of E-Commerce Among SMEs in the West Coast Sabah, Malaysia" Available at: http://www.arraydev.com/commerce/JIBC/2006 -08/Bolongkikit.asp (Accessed 20 April 2012).

[10]Turban, E., King, D., Viehland, D. and Lee, J. (2006). " Electronic commerce. " A Managerial Perspective, 4th Edition, Pearson, Prentice Hall

[11]Quayle, M. (2002). "E-commerce: the Challenge for UK SMEs in the Twenty-First Century." International Journal of Operations \& Production Management 22(10): 1148-1161.

[12]XiaoHui, H. and Z. Long. (2010). "ECommerce Strategy for SMEs. " Information Management and Engineering (ICIME), The 2nd IEEE International Conference on.

[13]Stockdale, R. and C. Standing (2006). "A Classification Model to Support SME ECommerce Adoption Initiatives." Journal of Small Business and Enterprise Development13(3): 381-394.

[14]Simmons, G., G. A. Armstrong, et al. (2008). "A Conceptualization of the Determinants of Small Business Website Adoption." International Small Business Journal 26(3): 351-389..

[15]Simpson, M. and A. J. Docherty. (2004). "ECommerce Adoption Support and Advice for UK SMEs." Journal of Small Business and Enterprise Development 11(3): 315-328.

[16]Scupola, A. (2009). "SMEs E-Commerce Adoption: Perspectives from Denmark and Australia." Journal of Enterprise Information Management 22(1/2): 152-166. 
Ahmed .L

[17]Kartiwi, M. and R. C. MacGregor. (2007). "Electronic Commerce Adoption Barriers in Small to Medium-Sized Enterprises (SMEs) in Developed and Developing Countries: A Cross-Country Comparison." Journal of Electronic Commerce in Organizations (JECO) 5(3): 35-51.
[18]Cronbach's Alpha, (2017).

http://www.cronbachsalpha.com. Accessed on 2 October 2017.

[20]Mitchell, V. (1996). "Assessing the Reliability and Validity of Questionnaire: an Empirical Example Journal of Applied Management Studies, 5, 199-207. "

\title{
العوامل التي تؤثر على تبني التجارة الإكترونية في الثركات الصغيرة والمتوسطة الحجم في العراق
}

\author{
احمد لؤي احمد \\ جهاز الإثراف والتقويم العلمي ,قتم الاعتماد الدولي \\ وزارة التعليم العالي والبحث العلمي ــ العراق
}

ahmed.qacc@gmail.com

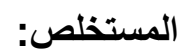

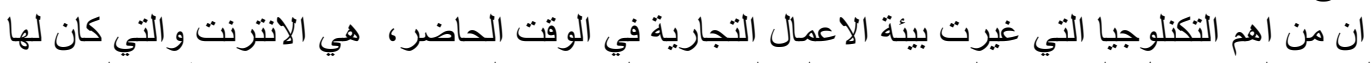

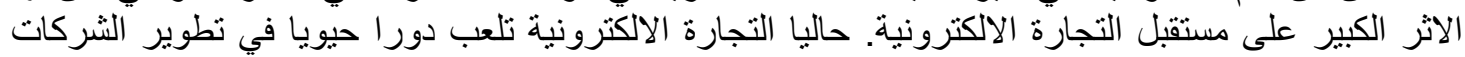

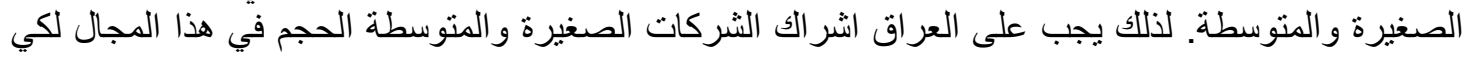

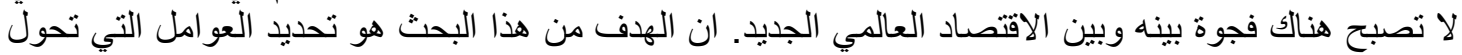

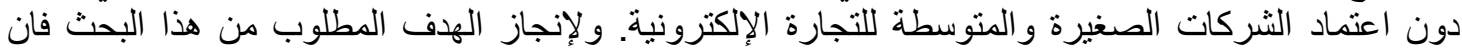

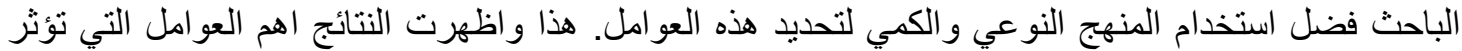

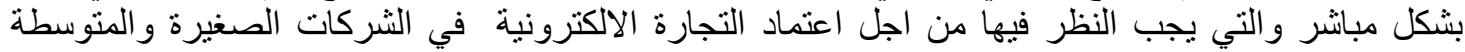

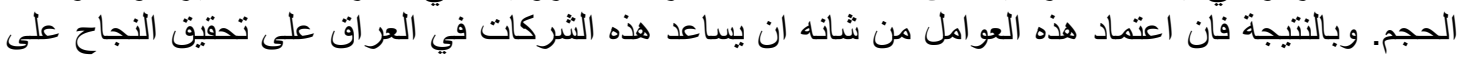

$$
\text { المدى الطويل في الاسو اق العالمية. }
$$

